\title{
A Negra de... e Moolaadè. Que África e teorias as lentes de Sembène Ousmane nos revelam?
}

\author{
Maria Ignês Carlos Magno \\ Doutora em Ciências da Comunicação pela ECA-USP. Professora do Mestrado em Comunicação \\ da Universidade Anhembi Morumbi e da Fundação Escola de Sociologia e Política de São Paulo. \\ E-mail: unsigster@gmail.com \\ Celia Cristina Torres Correio \\ Doutoranda em Comunicação Audiovisual do Programa de Pós-Graduação em Comunicação \\ da Universidade Anhembi Morumbi. \\ E-mail: torres.celia@gmail.com
}

Resumo: A sugestão dos filmes A Negra de... e Moolaadè do cineasta senegalês Ousmane Sembène foi pensada no sentido de propor o conhecimento do cinema africano. A intenção aqui é aprender a olhar a África e suas histórias sob a lente de um diretor africano e as teorias que subjazem no interior das narrativas fílmicas.

Palavras-chave: cinema; cinema africano; Osmane Sembène, África; narrativas fílmicas.
Abstract: The movies Moolaadè and Black Girl from the Senegalese film director Ousmane Sembène were chosen as subject in order to present African cinema in this publication. We aim to look at Africa and its stories through de lens of an African movie director and the theories internalized within his filme narratives.

Keywords: movies; African cinema; cinema; Africa; Ousmane Sembène; film narratives.

Os clássicos são livros que exercem uma influência particular quando se impõem como inesquecíveis e também quando se ocultam nas dobras da memória, mimetizando-se como inconsciente coletivo ou individual. ${ }^{1}$ (Calvino, Ítalo).

Começamos a existir quando deixamos de olhar para nós através do olhar do vizinho.

(Perrault, Pierre. Cineasta canadense).

\section{INTRODUÇÃO}

Insônia, África, Franz Fanon, filmes de negro, filmes sobre negro, nomes, palavras, imagens, poesias, teorias. Insônia e a mão busca na pilha de livros ao

1. CALVINO, Ítalo. Por que ler os clássicos. São Paulo: Companhia das Letras, 2007, p. 10. 
lado da cama algum poema ou conto para acalmar a inquietação provocada pelos filmes A Negra de... e Moolaadè do cineasta africano Sembène Ousmane. É inevitável retomar um dos livros que permanece na cabeceira, mesmo quando os outros são recolocados na estante: Por que ler os clássicos, de Ítalo Calvino. Desta vez, o clássico não é um romance ou um conto, ou poesias, mas um livro lido e relido na juventude, esquecido ou "ocultado nas dobras da memória": Pele Negra, Máscaras Brancas do martinicano Franz Fanon. Por que Fanon na biblioteca particular como uma obra inesquecível? "Porque um clássico é um livro que nunca terminou de dizer aquilo que tinha para dizer", explica Calvino na tese de número seis de seu livro. Porque, continua Calvino (p. 10): "relendo um livro na idade madura, acontece reencontrar aquelas constantes que já fazem parte de nossos mecanismos interiores e cuja origem havíamos esquecido". Mas a questão é outra, não basta saber o sentido de reler uma obra na idade madura, mas entender por que assistir a um filme pela primeira vez pode ser uma experiência tão extraordinária quanto reler um livro na idade madura? Porque tão extraordinário quanto reler um clássico, é a experiência de ver nos filmes a possibilidade de reencontrar uma obra inesquecível. No encontro entre os filmes que vi e os clássicos que reli, pensei em sugerir para a resenha dois filmes do cineasta Sembène Ousmane: A Negra de... (1966) e Moolaadè (2004). A intenção aqui é aprender a olhar a África e suas histórias sob a lente de um diretor africano e as teorias que subjazem no interior das narrativas fílmicas.

\section{A ÁFRICA E O CINEMA DE SEMBÈnE OUSMANE}

Antes de ser assassinado em janeiro de 1960, Patrice Lumumba disse: "Um dia, a África terá uma palavra a dizer, um dia, a África escreverá sua própria história”. Essa frase de Lumumba tão repetida durante os anos 1960 gera uma pergunta: de que África Lumumba estava falando, se a África e os povos africanos sempre tiveram sua própria história? A resposta é simples, sabemos. A África de que falava Lumumba era a África colonizada pelos impérios europeus do século XVI e depois pelos demais países imperialistas dos séculos XIX e XX. Falava da África de quem arrancaram suas riquezas materiais como calaram sua poesia, sua filosofia, sua arte em geral. África colonizada, África de "milhões de homens em quem deliberadamente inculcaram o medo, o complexo de inferioridade, o temor, a prostração, o desespero, o servilismo", como escreveu o poeta Aimé Césaire, citado por Franz Fanon. África que o sistema colonial criou como criou o racismo. Colonialismo e racismo que segundo Fanon: “deveriam ser entendidos como modos socialmente gerados de ver o mundo e viver nele. Isto significa, por exemplo, que os negros são construídos como negros". Para

2. FANON, Franz. Pele Negra, Máscaras Brancas. Salvador: EDUFBA, 2008, p. 15. ele, "não haveria razão para as pessoas na África, na Austrália ou em outras áreas do Pacífico Sul pensarem sobre si mesmas em termos raciais"2. Era dessa África que Lumumba falava e que um dia teria a palavra e escreveria, ou 
reescreveria sua própria história. Palavras e histórias vistas e escritas das mais variadas formas. Uma delas o cinema.

Que a África e os africanos sempre foram filmados desde o início do século XIX é fato conhecido. Fossem as reportagens coloniais, fossem os filmes etnográficos. Cinema colonial e filmes etnográficos que se expandiram desde o início dos anos 1920. Filmes e documentários que mostravam os negros e as paisagens exóticas usadas para "testemunhar o poder civilizador, determinado em demonstrar e negar as ancestrais civilizações africanas" ${ }^{\text {. Discursos }}$ e imagens cinematográficas que a partir dos anos 1950 começam a mudar, quando os africanos se tornaram atores de suas próprias histórias e imagens. A passagem dos cineastas africanos para trás das câmeras vinha de um desejo de reconhecer os valores e a identidade africana. Daí o significado das palavras do cineasta canadiano Pierre Perrault, citado por Mikima: "Começamos a existir quando deixamos de olhar para nós através do olhar do vizinho". A título de exemplo, e considerando uma das definições do cinema africano como um corpus de filmes realizados sobre a África e os africanos independente da origem do realizador, podemos citar os filmes: África 50 (Afrique 50) do francês René Vautier, primeiro filme que denunciava a barbárie do poder colonial; Eu, um negro (Moi, um noir) de Jean Rouch, documentário que deixava ao negro a possibilidade de falar de si mesmo; além do filme de Chris Marker, As máscaras também morrem (Les estatues meurent aussi) que mostra a pilhagem feita pelos ocidentais na África. O filme de Paulin S. Vieyra e Mamadou Sarre, dois senegaleses que fizeram em Paris África sobre o Siena (Afrique sur Seine), de 1955. Com esse filme, que fala das condições dos estudantes africanos na França, o mundo descobriu as primeiras imagens feitas por africanos, segundo Rufin Mbou Mikima. Sambène Ousmane lança em 1963 a ficção O carroceiro (Borom Sarret) em que o problema colonial é o foco da narrativa. O importante a partir daqueles anos era que o africano se tornasse narrador de suas histórias e de suas imagens. Nesse contexto, Sambène Ousmane do Senegal, juntamente com Med Hondo da Mauritânia inaugurariam a primeira geração de cineastas africanos que se colocaram atrás da câmera para falar e deixar a África falar por ela mesma. Se o discurso da chamada primeira geração era anticolonial, a segunda geração, que teve como um de seus representantes o cineasta maliano Souleymane Cissé, trouxe um discurso sobre os regimes autoritários que se seguiram às independências.

Embora saibamos que existam outros cinemas africanos como o cinema do Magreb, da África do Norte, o cinema da África Ocidental, da África francófona, da África lusófona e da anglófona, Áfricas e cinemas, como querem alguns cineastas, nosso interesse para essa resenha é o cinema produzido por Sembène Ousmane, especialmente dois de seus filmes: A Negra de... (1969) e Moolaadè (2004). O primeiro conta a história de uma jovem senegalesa vai para a França trabalhar como babá na casa de uma família francesa. Lá tem sua visão idealizada do país confrontada pela realidade do trabalho. O segundo

3. MIKIMA, Rufin Mbou. Comunicação no Porto, março de 2011. 
narra a prática da mutilação do clitóris das meninas que vivem na vila de Djerrisso, em Burkina Faso. O filme conta a história de quatro meninas que recorrem à casa de Colle, uma mulher que não permitiu que sua filha fosse mutilada, e pedem que ela as proteja. Colle profere o moolaadè, direito de asilo ou proteção sagrada, que só quem o pede pode revogá-la. A escolha dos filmes e o tempo que os separam foram pensados no sentido de perceber nas temáticas tratadas, o que permaneceu e o que mudou no seu cinema.

Pioneiro do cinema negro africano, Sembène Ousmane, contrariando os colonizadores que "tinham cuidadosamente afastado seus alunos indígenas da tentação da criação cinematográfica" ${ }^{4}$ tinha consciência de que:

Desde o nascimento do cinema, os povos africanos submeteram-se à imagem do cinema ocidental e a seu movimento rítmico. Muitas vezes só se projeta nas telas da África Negra histórias de uma cretinice enfadonha, estranhas ao nosso modo de vida. E, se por acaso um negro trabalha nestes filmes, e geralmente como figurante, ou num papel de boy ou engraçadinho. Ele nunca consegue dar um passo ou pensar por si mesmo sem dor de cabeça. A sétima arte agiu unilateralmente com a África durante longo tempo, pois veiculou apenas um retrato do nosso universo ${ }^{5}$.

Como cineasta autodidata, filmou histórias da África Negra, com personagens, problemas e modos de viver de seu povo. Nos anos 1960, A Negra de..., ao lado de Mandato e Emitaï constituem, segundo Guy Hennebelle ${ }^{6}$, numa ordem de causalidade inversa, um quadro da sociedade senegalesa e africana em geral. Emitaï descreve um dos aspectos do regime colonial, que mobilizou para seu serviço os homens, alimentos e matérias-primas. O Mandato pinta as condições de vida da massa aglutinada em torno das grandes cidades, após a independência mal conquistada. E A Negra de... expõe, em termos quase clínicos, o processo que obriga numerosos africanos e, no caso, africanas, a emigrarem para a antiga metrópole, e relata o modo como nela são tratados. São filmes que têm o colonialismo e a situação dos senegaleses depois da independência como temáticas. Em uma de suas análises considerada profética, Franz Fanon escreveu: "após a independência a burguesia nacional cada vez mais dá as costas para o interior, para a realidade do país inculto, e olha para a antiga metrópole, para os capitalistas estrangeiros que se apoderam de seus serviços"7. Fanon, dizia que gostaria de transformar o negro em um ser de ação, e acreditava que só pela consciência e pela ação a realidade poderia ser transformada. Ousmane também acreditava que era necessário não apenas pensar sobre a realidade em que se vive, mas transformá-la.

4. HENNEBELLE, Guy.

Os cinemas nacionais contra Hollywood. Rio de Janeiro: Paz e Terra, 1978, p. 155.

5. VIEYRA, 1973.

6. Idem, ibidem.

7. Fanon, op. cit., p. 156.
Sembène pertencia a uma vertente de cineastas africanos conhecidos como materialistas e revolucionários. Vejamos então como tratou, pelas imagens, a situação dos senegaleses que foram obrigados a emigrar para a metrópole após a independência.

O filme inicia com a imagem de um navio chegando à França. A bordo, Diouana contempla a cidade onde trabalhará como babá na casa de uma família francesa. A trajetória de Diouana, no entanto, começara em Dakar, quando decide 
ajudar sua família e sai em busca de trabalho. Depois de procurar e bater em várias portas um homem lhe indica o centro da cidade como o melhor local para arrumar emprego. Um lugar onde as moças dispostas a executar trabalhos domésticos se expunham como peças para serem admiradas e escolhidas. Como mercadoria, Diouana foi selecionada e contratada para o emprego de babá, em Dakar e depois em Paris. E assim começa a saga da Negra de...

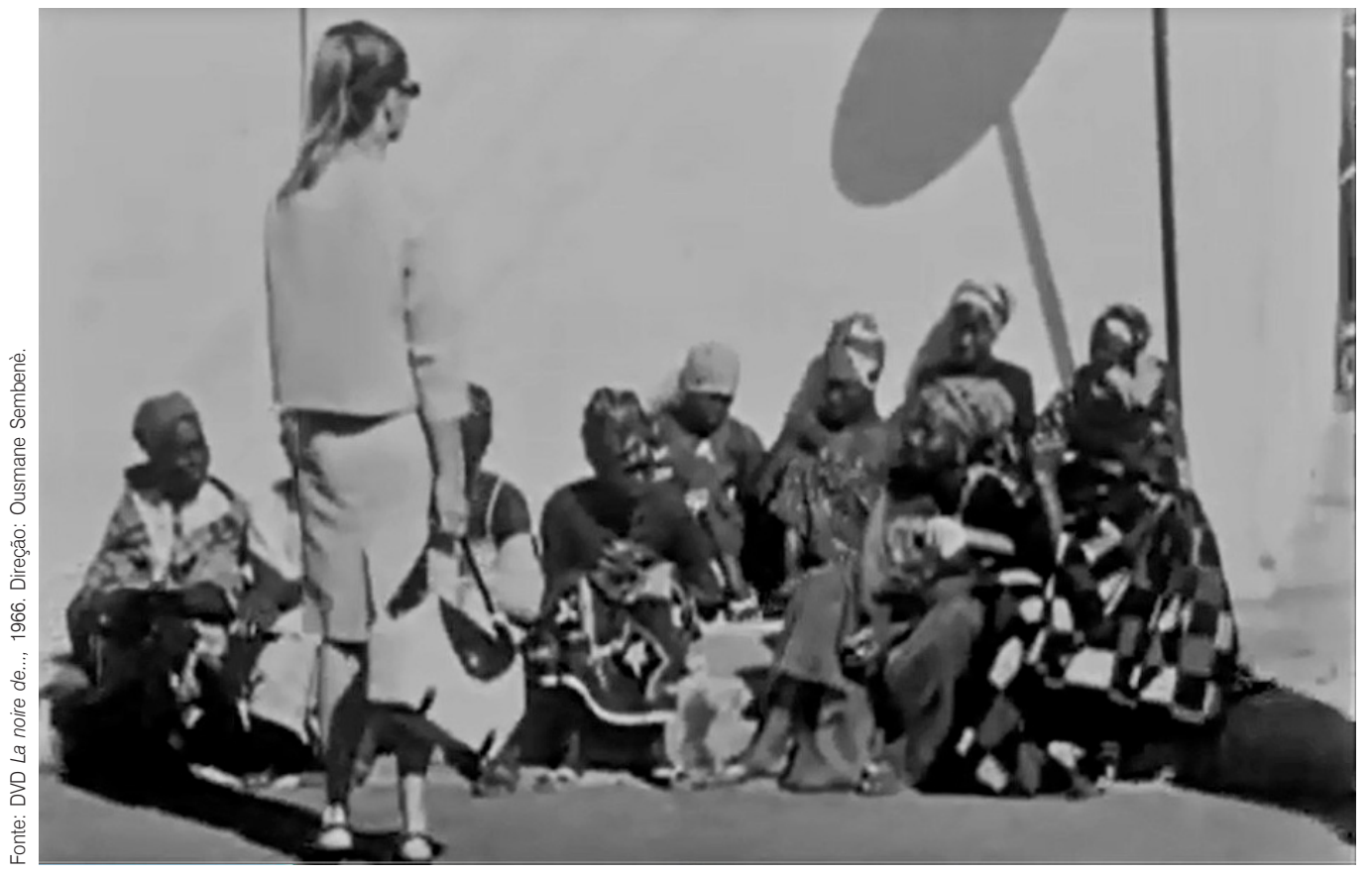

Como a narrativa do filme não é linear, para efeito de compreensão, os textos e as imagens foram trazidos de forma cronológica. Diouana deixa sua família no Senegal e vai para a França. Seu objetivo era trabalhar e conseguir melhores condições de vida para a família. Desde seu desembarque em Paris, os conflitos tanto de ordem interna como externa ficam latentes. O primeiro deles está no traje de Diouana. Veste-se como uma europeia, vestido de poá, brincos de margarida, sapatos altos. Mesmo colonizadas, as mulheres de Dakar mantinham os trajes de seu povo de origem. Despida dos trajes típicos, como emigrada, carregava a crença de que a vida na metrópole era melhor e de que conseguiria ajudar sua família. Os conflitos culturais, de identidade, e principalmente, econômicos não se limitam a essa mudança, vão se agravando a cada movimento do filme. 


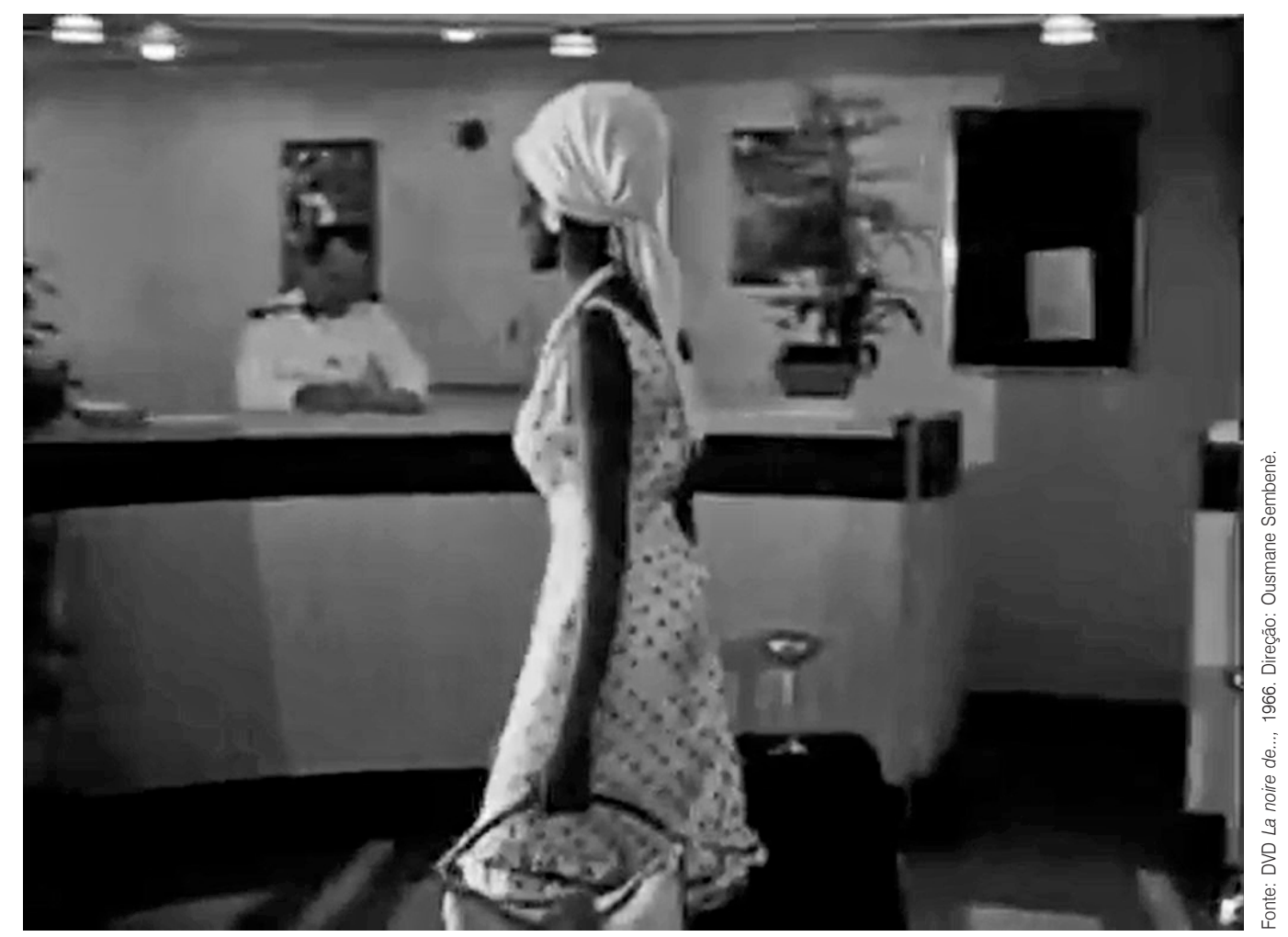

Diouana percebe que durante o período em que trabalhou com essa família em Dakar era bem tratada, lá desempenhava sua função de babá. Quando chega a Paris, essa relação é completamente alterada e passa a ser tratada como empregada doméstica, envolta em toda ordem de preconceitos e racismos. Momento da história em que Diouana começa a perceber o processo de sua anulação como pessoa, viver o peso do desligamento de suas raízes e sentir a frustação do que esperava naquela terra estrangeira. Nesse momento, as reticências do título do filme permitem ao espectador fazer suas análises e talvez chegar a uma leitura possível: quem é ou de quem é Diouana?

Aqui interessa retomar a cena em que Diouana presenteia seus patrões com uma máscara típica de sua aldeia, como forma de agradecimento pela oportunidade. A máscara foi colocada em uma parede branca sem nenhum outro objeto. Sozinha na parede branca, a máscara era a única referência de seu povo e de suas origens. O presente que inicialmente era um objeto de seu lugar de origem ao longo da narrativa se tornou o elo entre Diouana, suas memórias e sua cultura. No movimento conflituoso de seu ser ou não ser, o sentimento de ódio pelos maus tratos e as perguntas: Quem sou eu? O que vim fazer nesse lugar?, e consciência de que uma nova forma de escravidão fora instaurada após a independência. Na parede branca, a máscara negra não representava mais a identificação ou a materialidade de sua cultura, mas a possibilidade de reflexão. 


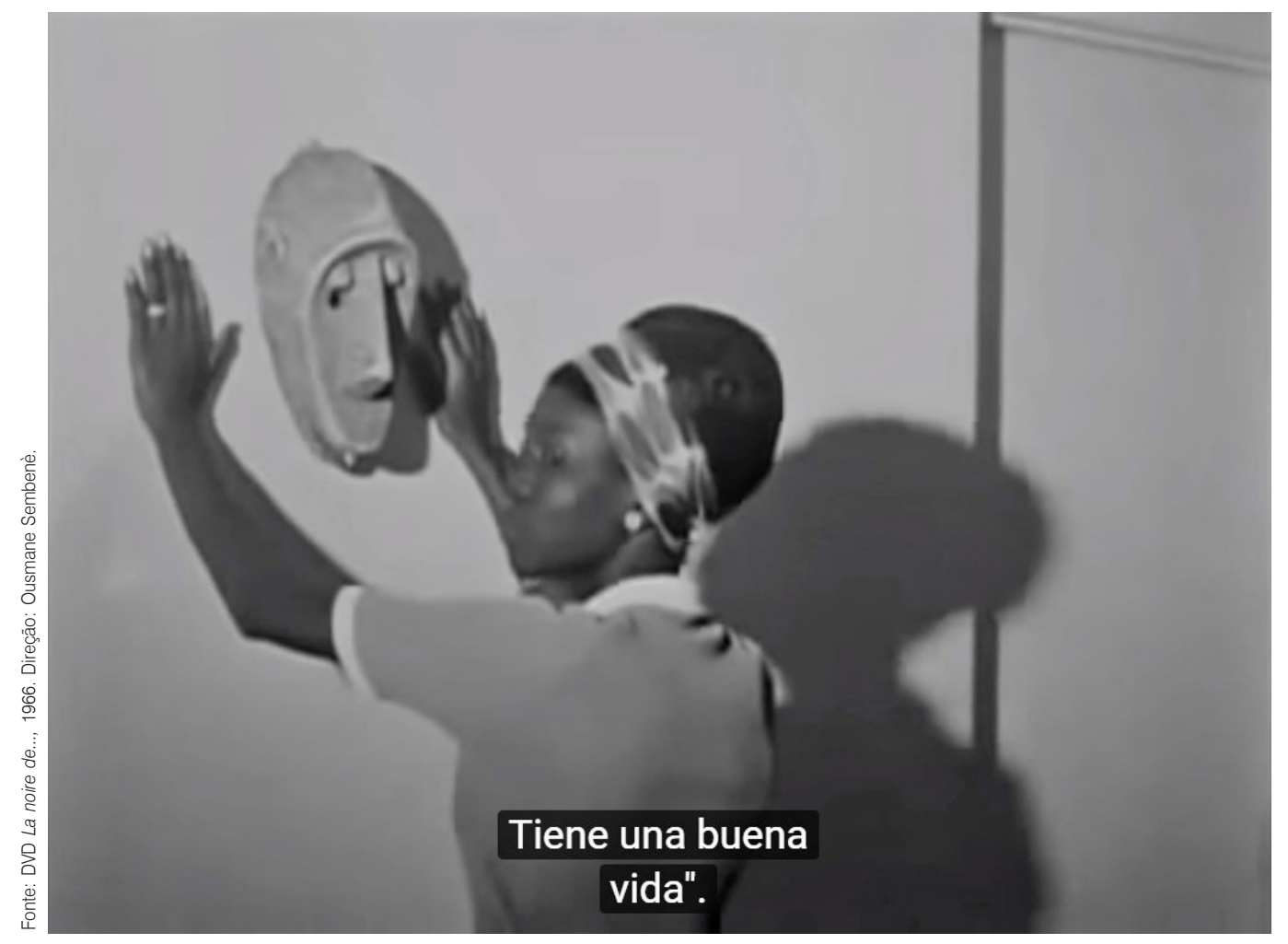

Aos 18' de filme a vida da Negra de... muda completamente e a narrativa toma caminhos inesperados para o espectador. Ousmane ao trazer à tona discussões sobre relações de trabalho, discriminação e preconceitos do tipo "Posso te beijar? Eu nunca beijei uma negra" ou algo ainda mais intenso quando se refere a compreensão de Diouana e o idioma francês ("ela fala francês, ou só compreende, como os animais, por instinto”), coloca o espectador frente a situação de puro racismo, e de questões que passam pelas relações entre o negro e o branco; a erotização do corpo negro e o conhecimento da língua como forma de dominação. Questões amplamente colocadas e discutidas por Fanon em seu livro Pele Negra, Máscaras Brancas (1952) e que estão presentes no filme, como estão presentes a resistência, a consciência corporal e a ação como forma de libertação. Mesmo quando ela se dá de maneira trágica como é o caso de $A$ Negra de...

Desde que chegou a Paris, ela se veste com as roupas e sapatos que sua patroa lhe deu em Dakar. Para não dizer que não usa nenhuma peça de seus antigos trajes, restou-lhe as sandálias que vestia à noite. O início de sua resistência começa quando a patroa lhe diz que não precisa colocar salto alto para executar serviços domésticos. Diouana tira os sapatos e os deixa no meio do caminho, como gesto de revolta por estar sendo tratada daquela maneira.

Na manhã seguinte, Diouana já está sentada para o café da manhã quando a patroa lhe pergunta: "Você está doente? Se não estiver doente, aqui quem não 


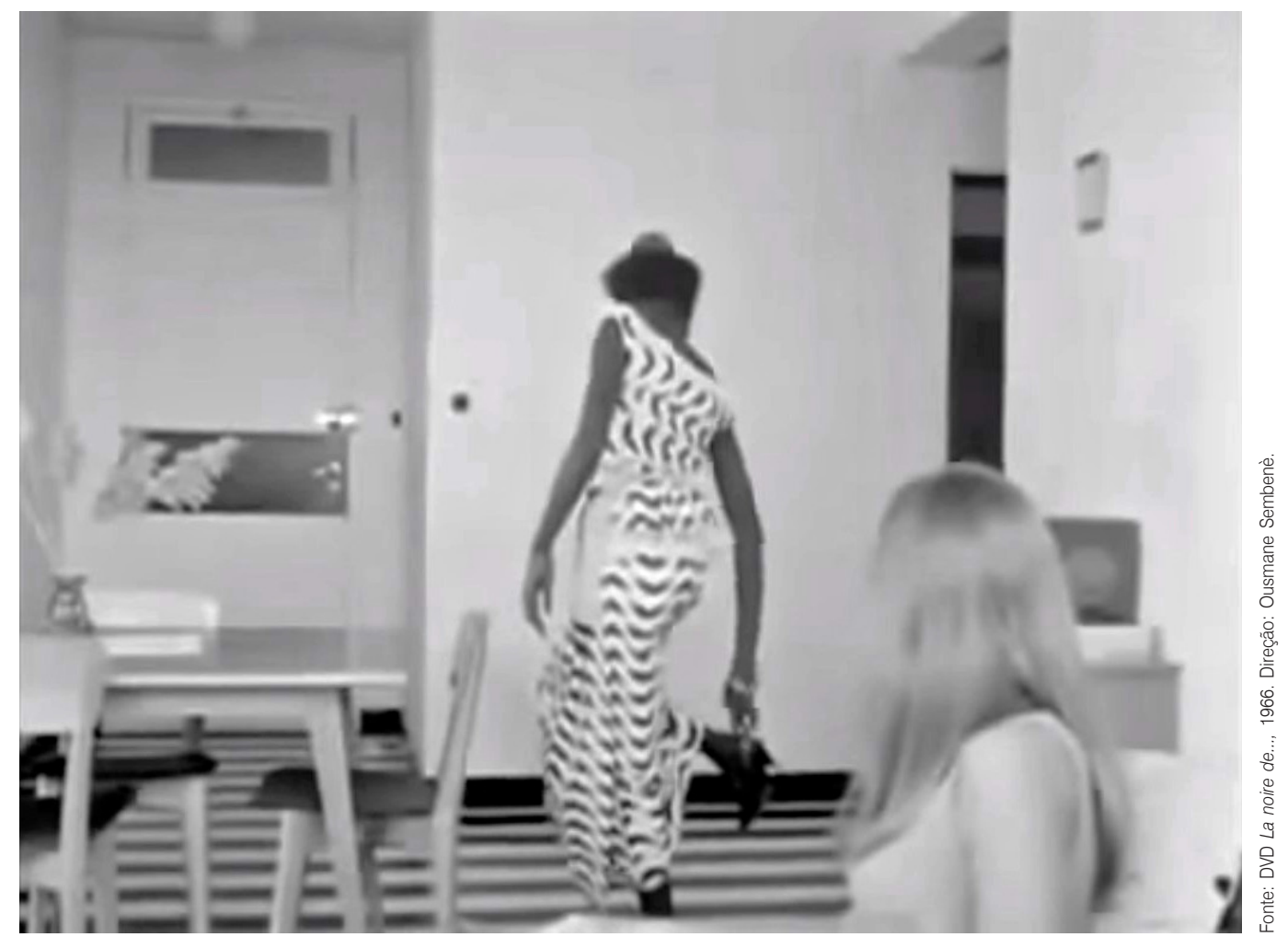

trabalha não come". Diouana em outro gesto rebelde diz: "Se não como, não cuido das crianças". A resistência, que passa a fazer parte de suas atitudes após a consciência de sua realidade, acompanhou Diouana até o seu trágico final. Explorada economicamente, pois não recebia o salário prometido, desacreditada por seus familiares já que não lhes enviava dinheiro, após uma discussão com a patroa, tira o avental e joga nos pés do patrão. Ao receber o salário, em um gesto de revolta e de ação, devolve o dinheiro aos patrões, despe-se das roupas europeias, entra na banheira e corta o pescoço com uma navalha. A máscara negra que havia retirado da parede branca repousava silenciosa sobre sua mala. A máscara retornou à vila onde morava em Dakar, seu lugar de origem. Em uma sequência tão emblemática quanto a máscara, o menino coloca a máscara no rosto e persegue o patrão até ele ultrapassar a ponte que divide a cidade e desaparecer. Lentamente, o menino retira a máscara do rosto.

Moolaadè (2004), palavra africana que significa direito de asilo ou proteção sagrada, difere de A Negra de... (1969). O filme não conta uma história das relações coloniais, nem dos diferentes tipos de racismo, nem da violência da colonização branca sobre os africanos. Nesse filme, Ousmane Sembène mostra os africanos no interior de suas relações cotidianas e de uma tradição praticada até os dias atuais, a salindé (ablação) e o moolaadè (proteção). Mostra o enfrentamento entre o direito de asilo e a tradição da ablação, ou a mutilação ou extirpação do clitóris das meninas em nome da purificação. As meninas que não passam pelo processo de purificação são chamadas de bilakoro. São 


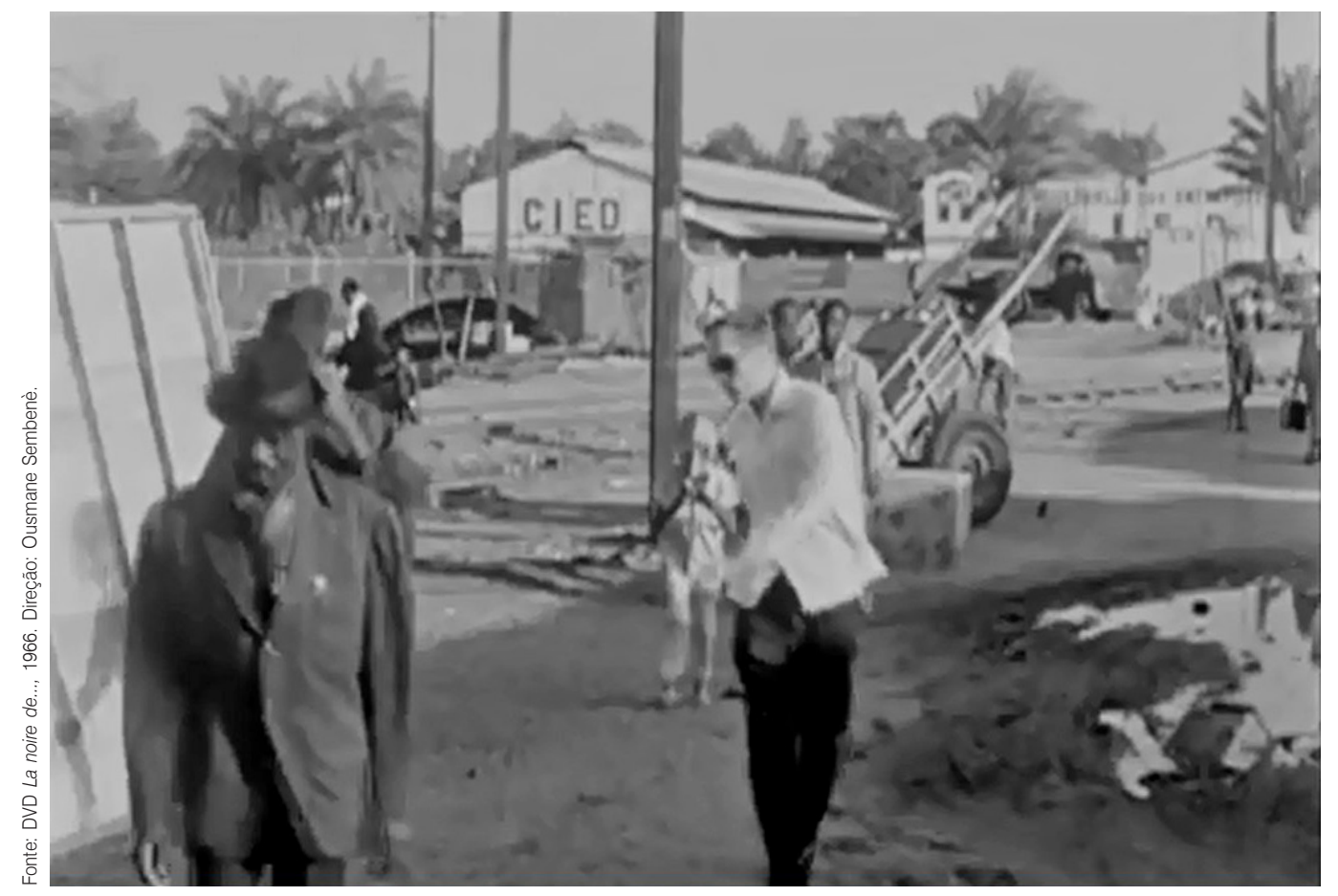

desonradas. Especificamente a história ocorre na pequena vila de Djerrisso em Burkina Faso, onde a tradição se mantém. Essa prática não é geral na África. $\mathrm{O}$ filme começa com a imagem de quatro meninas fugindo do rito de purificação e se refugiando na casa de Colle, uma das mulheres da vila que não havia permitido que sua filha Amsatou fosse mutilada. As meninas pedem que Colle as proteja. Colle profere o moolladè (proteção) que protegerá as meninas da ablação (salindé) realizada pelas salindanas (sacerdotisas responsáveis pela ablação).

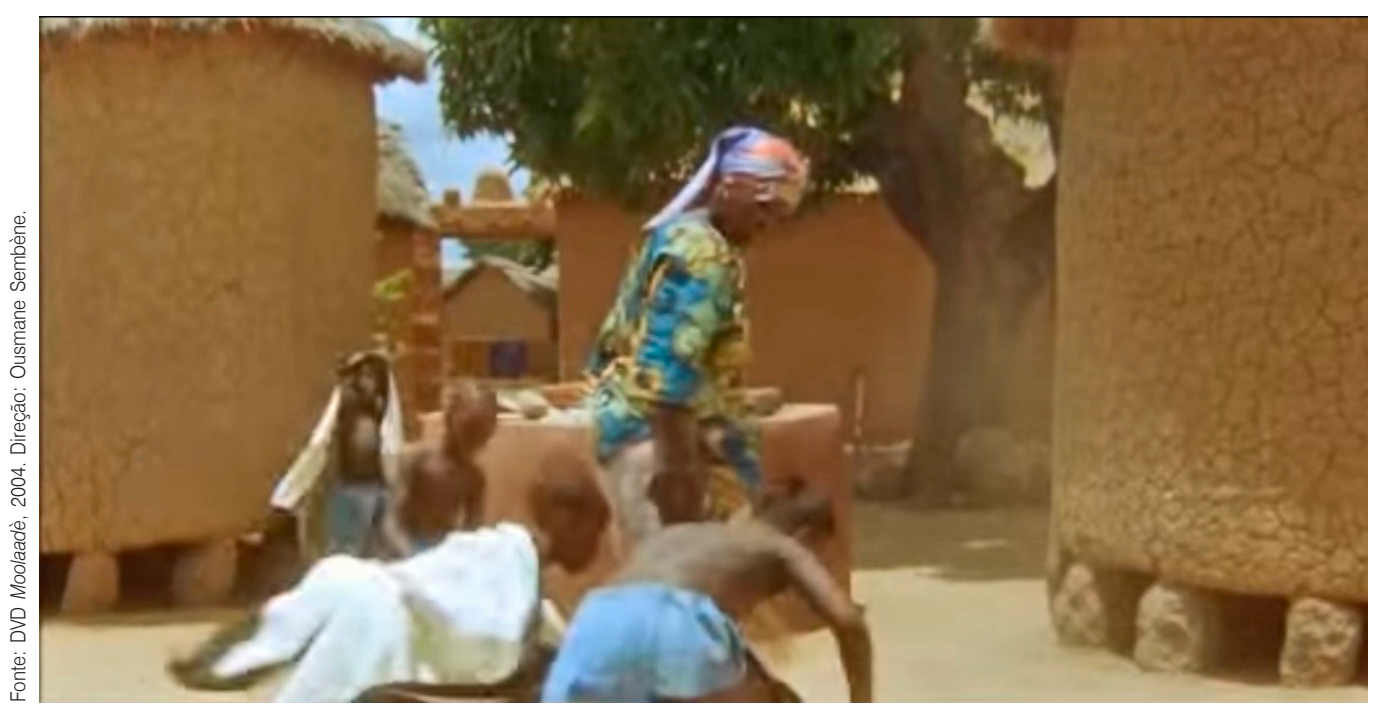


Moolaadè é uma antiga palavra pulaar, que existe também em mandinga e em wolof, enquanto a salindé é uma palavra sarakolé ou mandinga. Seguindo a explicação de José Paz Rodrigues ${ }^{8}$, o ritual da salindé é um acontecimento na vida de uma mulher e costuma ter lugar aos 7 anos. Durante duas semanas que precedem a entrada no bosque sagrado, as mães e as tias preparam psicologicamente as meninas para aguentar a dor sem berrar, sem se queixar. Devem controlar e dominar a mordedura viva e abrasadora do cuitelo. Se puder com a dor, a moça demonstrará quando a mulher será capaz de sobrepor-se aos tormentos e aflições da existência. Ao contrário, uma menina que não passou pela ablação é uma bilakoro, em malinké. É impura e não pode se casar. A $s a$ lindé, de acordo com a tradição, coloca a menina ao nível da esposa, eleva-a à categoria da realeza. A mulher que passou pela ablação simboliza a pureza. É uma honra para seu esposo e para sua família. Essa explicação interessa uma vez que é a base para a trama do filme.

Um ponto de partida para tornar visível a complexidade das relações existentes em determinadas regiões e sociedades com suas instituições e leis, e desafiar nosso olhar estrangeiro. Não é por acaso que Ousmane começa o filme com a chegada de um estrangeiro na vila, e nós entramos junto com o mercenário para dentro da vila e da complexidade das relações nas sociedades rurais africanas. O desafio que nos propõe é constante e intenso. A começar pelas construções, a organização arquitetônica das casas, do templo, da poligamia, dos espaços de trabalho e os de convivência. Um deles, o poço onde as mulheres buscam água e conversam sobre tudo, onde expõem suas ideias ou contam casos. Foi em torno do poço e ouvindo as conversas das mães que as meninas ficaram sabendo que Colle não havia permitido que sua filha, Amsatou, entrasse no bosque sagrado e fosse mutilada pelo cuitelo das salindanas. Se Amsatou foi protegida pela mãe que desafiou a salindé, por que não as protegeriam? Daí a fuga e o pedido de proteção na casa de Colle. E nossos conhecimentos e conceitos sobre as sociedades africanas e suas leis são novamente postos em questão. Se é visível que Ousmane denuncia a prática da ablação em pleno século XXI, como ele mesmo disse em entrevista: "Vimos de entrar no século XXI que as mutilações genitais femininas continuam vigentes em mais de 25 países africanos repartidos a leste, oeste, norte e sul do continente entre os 54 membros da OUA reconhecidos na ONU", é visível também o quanto nos obriga a olhar para a África e para sua história de outra maneira. Se é impossível ficar indiferente frente à prática do salindé que vigora até hoje, é impossível igual não pensar na força do moolaadè que também vigora até os dias atuais. Mais desafiador ainda é saber e ver a força da tradição e da oralidade. Na África, quem pede moolaadè, pede asilo, pede proteção, e essa proteção é

8. RODRIGUES, José Paz.

Fomentar na escola a solidariedade com os povos da África através do filme Moolaadè. Diário da liberdade. 23 maio 2013. sagrada porque é inviolável e inquestionável pelos membros da comunidade. Ao proferir o moolaadè a mulher fecha o espaço com um cordão colorido que ninguém da vila se atreve em ultrapassar. Ninguém viola o moolaadè. Nem as salindanas. 


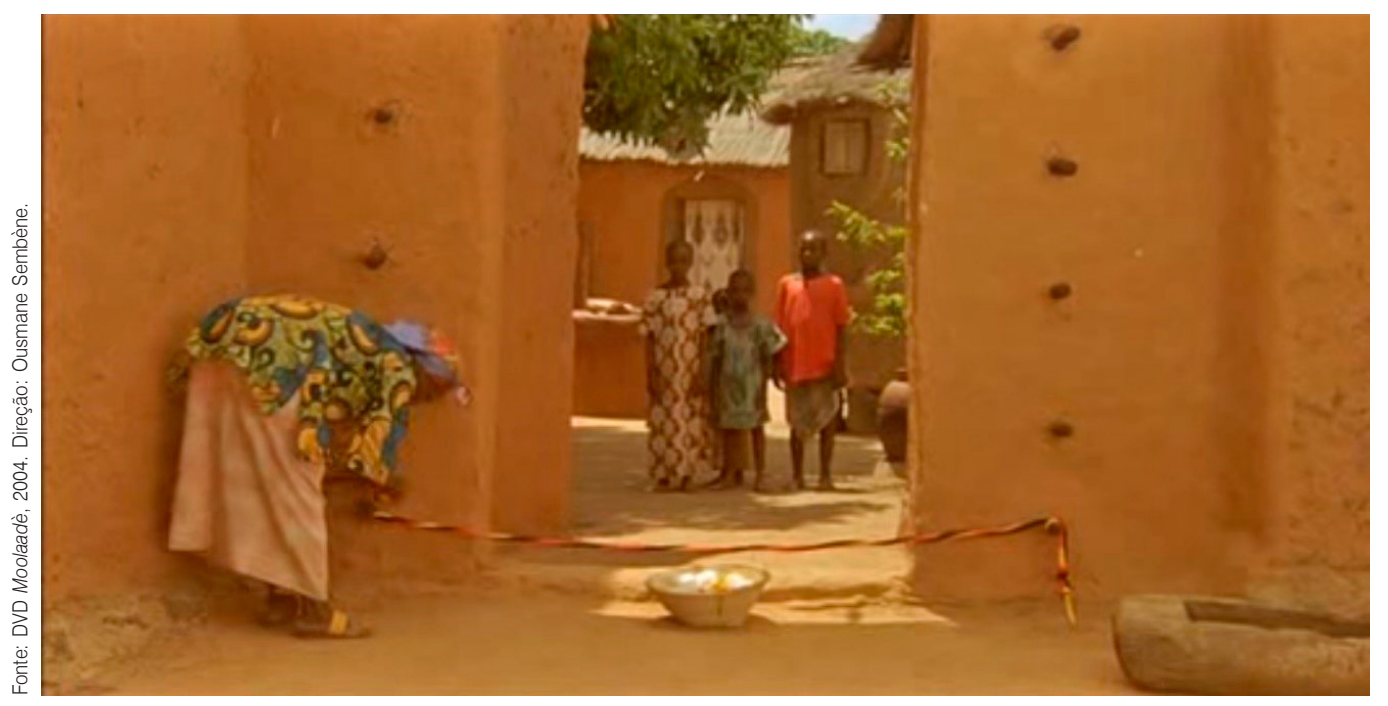

O moolaadè é uma convenção oral com valor jurídico pleno, transmitido de geração em geração, possui regras e decretos que toda a coletividade conhece, reconhece e respeita incondicionalmente, nos coloca Rosabel Argote ${ }^{9}$. Só quem o proferiu pode revogá-lo. Esse é um dos pontos em que o conflito é estabelecido entre Colle, o direito de asilo e os anciãos que pretendem que ela revogue o pedido e entregue as meninas para as salindanas. Como o marido não a convence e nem os anciãos da vila, encabeçado pelo irmão mais velho de seu marido, Colle é levada para o centro da aldeia e chicoteada em público pelo marido. Sob os olhos de toda a população, ela apanha. Quase desmaia e as mulheres pedem que ela resista. Morreria apanhando se não fosse a interferência do mercenário, que, apesar de ter vivido tantas guerras, não suportou o que viu. À noite, os homens da vila pintam o rosto de branco, a cor da máscara da morte, e executam o mercenário.

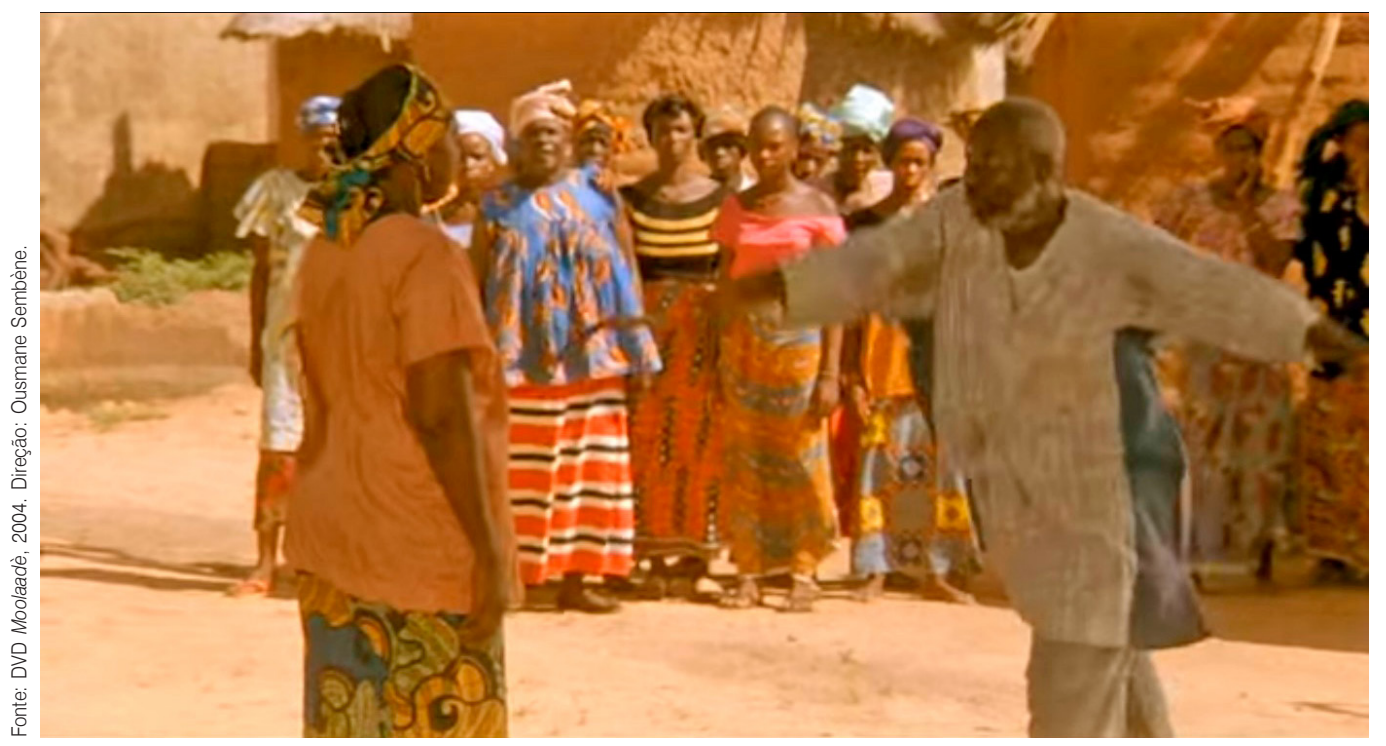

9. ARGOTE, Rosabel. Moolaadè, o la protección de quienes huyen de la ablación. Uma leccíon de Africa a Occidente em matéria de derecho de asilo. Revista Mugak, n. 42, 2011. 
Ela não desiste, não desmaia e não revoga o pedido de moolaadè. Colle é levada para sua casa e tratada pelas outras mulheres de seu marido e pela filha, Amsotou. Nome dado em homenagem à médica que a ajudou no parto, depois de Colle ter perdido duas crianças por causa da mutilação que havia sofrido. Diante da negação que uma menina não "purificada" é submetida, Colle diz para a filha não se envergonhar de ser uma bilakoro, porque o fato não "a impedia de ser uma boa esposa, uma boa mãe, nem saber cuidar do esposo". "A purificação não é boa", afirma para a filha. Colle se recupera fisicamente das feridas. Em um dos momentos de conversação entre as mulheres, sob uma grande árvore, uma delas chora desesperadamente a morte da filha durante o ritual. Lembra a filha sangrando e morrendo em seus braços. Esse é o ponto limite para elas. Juntamente com outras mulheres da vila, Colle vai ao encontro dos anciãos e das purificadoras que no início tinham dito que "a purificação é uma tradição e ninguém pode se opor a uma tradição". É o momento do enfrentamento, do duplo enfrentamento: com a tradição e com a violência contra as mulheres. A rebelião toma conta da vila e sob o grito "Wasa! Wasa!" colocam um fim ao ritual. Sob o olhar de todos os homens, inclusive de seu marido, que a despeito de tê-la chicoteado a mando do irmão mais velho, olha para Colle com admiração. Admiração também do filho do mais poderoso ancião do lugar, que vivia na França, voltou para se casar e escolhera para Amsotou como esposa.

Tudo isso frente a uma enorme fogueira dos rádios confiscados pelos homens da vila para que as mulheres não se informassem. Atrás da fogueira, a mesquita com uma antena de televisão. Embora esses aspectos, como os aspectos referentes ao casamento e às influências culturais não tenham sido mencionados nessa resenha, é importante reproduzir a fala de Ousmane sobre as antenas: "A antena da TV diz claramente que África não pode ficar fechada em si mesma. Deve abrir-se ao futuro. Devemos mudar de comportamento, mas nós devemos

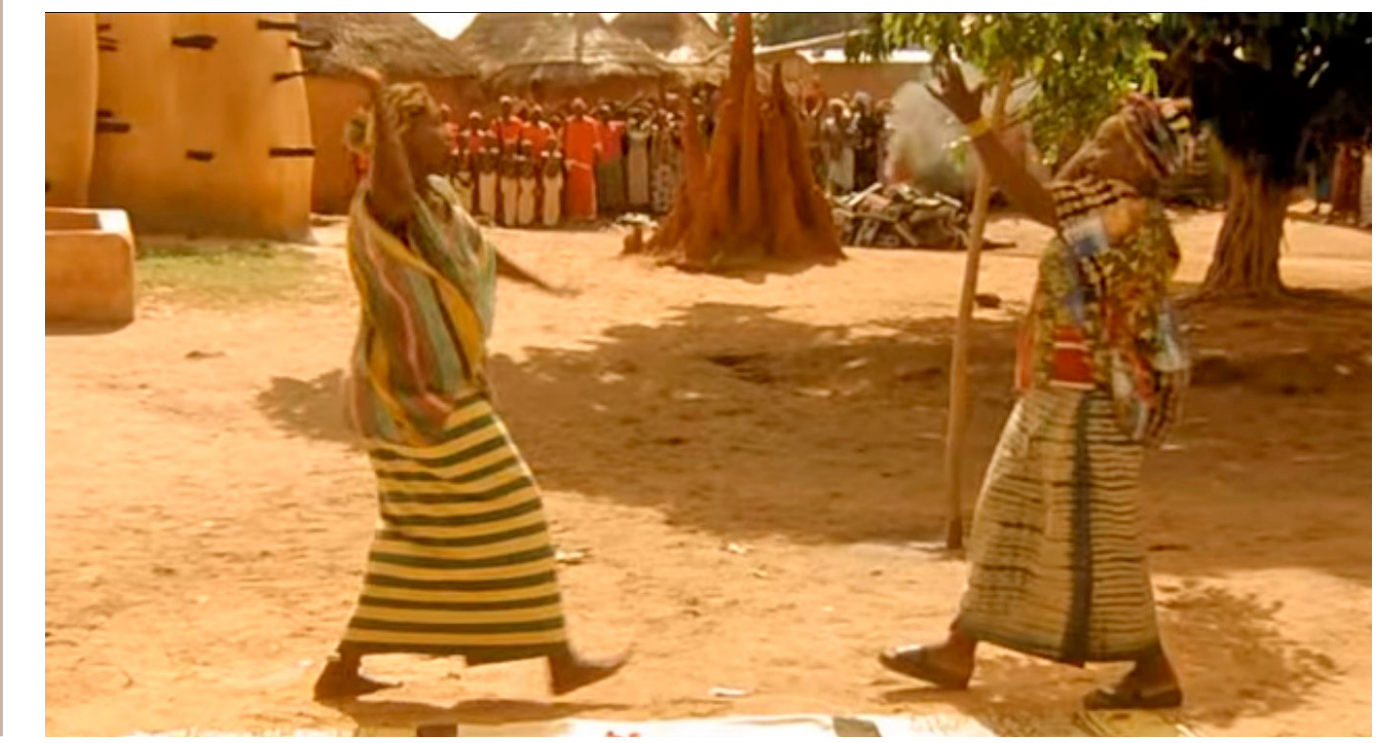


decidir por nós”. Fala que nos remete novamente ao princípio: colocar-se atrás da câmera e narrar as histórias da África com olhos próprios e não com os do vizinho. Mas colocar-se atrás da câmera e narrar uma história pressupõe escolhas e posicionamento. E aqui um dos pontos de contato entre A Negra de... e Moolaadè e o posicionamento teórico do cineasta: os dois filmes têm a mulher como foco central da reflexão e por meio das histórias dessas mulheres permanece a teoria que acompanhou Ousmane desde sempre, a teoria da ação como forma de libertação. Em A Negra de..., a tomada de consciência de si é individual e a ação também. Em Moolaadè, a tomada de consciência é coletiva e a ação pressupõe a transformação da realidade. Em ambos os filmes é possível ver trechos da prece final de Fanon: "[...] Que jamais o instrumento domine o homem. Que cesse para sempre a servidão do homem pelo homem, ou seja, de mim por um outro. Porque "É através de uma tentativa de retomada de si e de despojamento, é pela tensão permanente de sua liberdade que os homens podem criar as condições de existência ideais em um mundo humano"10. A tomada de consciência seja ela individual ou coletiva passa pela consciência do corpo como forma de existir, de pensar e de transformar o mundo. Não por acaso a última prece de Fanon termina assim: "Ó meu corpo, faça sempre de mim um homem que questiona!" 11 . Não por acaso que a cena final de Moolaadè é Amsotou e o noivo se olhando e ela diz que é sempre será uma bilakoro. Ele apenas olha para ela e sorri. Os corpos livres encenam uma dança.

\section{REFERÊNCIAS BIBLIOGRÁFICAS}

ARGOTE, Rosabel. Moolaadè, o la protección de quienes huyen de la ablación. Uma leccíon de Africa a Occidente em matéria de derecho de asilo. Revista Mugak, n. 42, 2011.

CALVINO, Ítalo. Por que ler os clássicos. São Paulo: Companhia das Letras, 2007

FANON, Franz. Pele Negra, Máscaras Brancas. Salvador: EDUFBA, 2008.

HENNEBELLE, Guy. Os cinemas nacionais contra Hollywood. Rio de Janeiro: Paz e Terra, 1978.

MIKIMA, Rufin Mbou. Comunicação no Porto, março de 2011.

RODRIGUES, José Paz. Fomentar na escola a solidariedade com os povos da África através do filme Moolaadè. Diário da liberdade. 23 maio 2013. 